\title{
SEPARACIONES, TRANSFORMACIONES Y DIVERGENCIAS: HILACHAS CULTURALES SOBRE LA AUTONOMIZACIÓN DE LA ECONOMÍA EN OCCI-DENTE
}

\author{
Ernesto García López \\ Antropólogo Social y Cultural \\ Consultor experto en Cooperación Internacional y Desarrollo Local \\ http://dx.doi.org/10.5209/rev_NOMA.2012.v35.n3.42196
}

\begin{abstract}
Resumen.- El 15 de mayo de 2011 comenzó un movimiento internacional de indignación contra los poderes políticos y, en especial, económicos. En el centro de la protesta habitaba el rechazo a los "Planes de Ajuste" impulsados por varios gobiernos europeos con motivo de la crisis. Las diferentes democracias occi-dentales parecían plegarse a los intereses de "los mercados" en contra de la voluntad de muchos de sus ciudadanos. ¿Por qué ejerce la economía su dominio sobre la política? ¿Cuáles serían algunos de los rasgos históricoculturales que modelan esa relación? ¿Es la crisis financiera actual una implosión sorpresiva o existen bases suficientes como para considerar que sus raíces se hunden en una determinada configuración sociocultural? Mediante el repaso de ciertos autores que han reflexionado sobre estos asuntos se identificarán algunos elementos que explican la autonomización de la economía y el sometimiento de la política a sus lógicas, condicionamientos y presupuestos teóricos.
\end{abstract}

Palabras-clave.- Política, economía, individualismo, globalización, feminismo, decolonialidad

\begin{abstract}
The 15th of May of 2011 an International outraged social movement started against the political powers and especially against the economic ones. The nucleus of this social movement was the rejection against the "Budget reduction plans" boosted by the different European governments due to the economic crisis. The different western democracies seemed to submit to the interests of "the markets" against the will of most of its citizens. Why is economy controlling politics? Which are the historical and cultural characteristics that shape this relationship? Is the actual financial crisis a surprising explosion or are there enough proofs to consider that its roots exist in a concrete socio-cultural configuration? Through a revision of different authors who have reflected about these topics, I will analyse some elements that explain the autonomous working of economy and the subjection of politics to its logics, conditions and theoretical proposals.
\end{abstract}

Keywords.- Politics, economy, individualism, globalization, feminism, decoloniality

\section{Estampas de la crisis}

Empecemos con tres imágenes. 15 de mayo de 2011. Puerta del Sol, Madrid. Tras una manifestación convocada por medios de las redes sociales, da comienzo una acampada que sembrará la semilla de lo que se ha conocido como Movimiento de los Indignados ó 15M. Miles de ciudadanos ocupan la histórica plaza y abren un proceso de desobediencia civil bajo el lema "No nos representan". En el texto del comunicado de prensa de "Democracia real YA" (del 17/05/2011) se dice: "Nosotros los desempleados, los mal remunerados, los subcontratados, los precarios, los jóvenes... queremos un cambio y un futuro digno. Estamos hartos de reformas antisociales, de que nos dejen en el paro, de que los bancos que han provocado la crisis nos suban las hipotecas o 
se queden con nuestras viviendas, de que nos impongan leyes que limitan nuestra libertad en beneficio de los poderosos. Acusamos a los poderes políticos y económicos de nuestra precaria situación y exigimos un cambio de rumbo." 4 de diciembre de 2011. La Ministra de Trabajo italiana, Elena Fornero, rompe a llorar mientras expone los recortes que acaba de decretar el gobierno "técnico" de Mario Monti. Las medidas afectarán unos 25.000 millones de euros, entre los que se encuentra el retraso de la edad de jubilación y la subida de impuestos. ${ }^{1}$ Fijémonos de nuevo en los detalles de esa fotografía. La responsable máxima de los asuntos laborales en Italia acata la presión de los mercados y se ve en la obligación de inaugurar un durísimo paquete de ajustes. Por sus lágrimas intuimos que la decisión (de ser honesta) va más allá de su propia voluntad. Se trata de la expresión inquietante de lo subalterno, la metáfora perfecta que recrea el dominio de la economía sobre la política. Última estampa. 2 de enero de 2011. Rueda de prensa ante los principales medios de comunicación. Apenas una semana después de la toma de posesión del nuevo gabinete de Mariano Rajoy en España, su primer consejo de ministros acuerda (contra su propia promesa electoral) una subida generalizada de impuestos y un conjunto de medidas de ahorro público orientadas a "evitar una nueva crisis de la deuda"2. La plana mayor del nuevo ejecutivo, Soraya Sáenz de Santamaría (Vicepresidenta, ministra de la Presidencia y portavoz), Luis de Guindos (Ministro de Economía y Competiti-vidad), Cristóbal Montoro (Ministro de Hacienda y Administraciones Públicas) y Fátima Báñez (Ministra de Empleo y Seguridad Social) comparecen juntos y elucidan las razones por las cuales se han visto obligados a tomar esa decisión en contra de la intención inicial de no aumentar las cargas impositivas. Otra vez "los mercados" 3 y sus requerimientos económicos como causantes de tales delibera-ciones. La contemplación de estas imágenes nos empuja, casi irremediablemente, a formularnos varias preguntas: ¿Cómo se ha llegado a esta situación? ¿Por qué la economía (y su correlato metafórico, los mercados) se enseñorean de ese modo y doblegan cuantas voluntades políticas se ponen a su paso? ¿Hay razones histórico-culturales capaces de explicar esta coyuntura?

La tesis que defenderé en el presente artículo es que la implosión de la crisis finan-ciera global hunde sus raíces en una malla dialógica de rupturas y/o separaciones epistémicas que han ido "autonomizando" la economía respecto de la política y la sociedad, llegando incluso a convertir en subsidiarias las segundas respecto de la primera. Asimismo, defenderé que esta autonomización es producto de una específica configuración sociocultural, la de Occidente, no universal, en contra-posición a otros mundos y cosmovisiones posibles, y cómo dicha configuración guarda una estrecha relación tanto con los procesos de colonialidad (en el sentido que los definen Walter Mignolo y Aníbal Quijano) como de división sexual del trabajo (en línea con los argumentos expuestos por Silvia Federici). Ahora bien, para discernir estos

\footnotetext{
1 Tomado del diario Público, 4 de diciembre de 2011, recuperado de http://www.publico.es/dinero/410538/la-ministra-de-trabajo-italiana-rompe-a-llorar-mientrasexplica-los-recortes

2 Tomado del diario El País, 2 de enero de 2011, recuperado de http://politica.elpais.com/politica/2012/01/01/actualidad/1325436876_572644.html

3 Utilizaré el entrecomillado para referirme, fundamentalmente, a ideas y conceptos que aparecen de ese modo en el discurso de los medios de comunicación.
} 
territorios de desgajamiento se hace necesario repasar varias aportaciones procedentes de las ciencias sociales y la historiografía que vienen persiguiendo, desde hace tiempo ya, la complejidad del fenómeno y las fuertes implicaciones que éste tiene en la articulación de las propias disciplinas científicas sociales. Dada la extensión del presente artículo carezco de voluntad alguna de completud. Sólo una investigación antropológica multisituada y multilocal (Marcus, 2001) de ciertos fenómenos del capitalismo y sus implicaciones sería capaz de discernir la intrincada red de eslabonamientos que afectan el fenómeno, de ahí que prefiera utilizar el término hilachas tomado como una suerte de apuntes que nos auxilien en la vislumbre de ciertas señas de identidad.

Adelanto, además, otra prevención. El repaso de autores, obras y enfoques tendrá un carácter progresivo. Transitaremos desde el corazón de la razón imperial o hegemónica (con un fuerte acento euroandrocéntrico) hasta un cierto despren-dimiento epistemológico que de cuenta de una contrarelato alternativo (Mignolo, 2008). Esto no quiere decir que no tome en consideración (ni sea sensible) al impacto que todo lo que se expondrá a continuación tuvo y tiene más allá del ámbito de Occidente y del universo de los varones, sino que el rescate de los textos y autores referidos al inicio persigue esclarecer cómo se gestó (desde una perspectiva cultural y patriarcal determinada) la narración sobre las categorías economía o política, para después tratar de imponer dicha visión al resto del planeta mediante procesos de colonización, violencia y conquista. De ahí que el texto intente también ofrecer una visión-otra conectada con las tesis del feminismo y el paradigma decolonial. Ahora bien, por detrás de todas las reflexiones recogidas tendremos muy presente la advertencia que el antropólogo Enrique Luque hiciera parafraseando a uno de los autores que (re)visitaremos, Mark Lilla:

De modo significativo, lo que Lilla viene a resaltar en su brillante recorrido por el pensamiento político occidental —en el que abarca desde sus orígenes judeo-cristrianos hasta los fundamentos filosóficos y teológicos de los totalitarismos del siglo $\mathrm{XX}$ - es algo en lo que la antropología ha venido insistiendo hace ya muchas décadas. Esto es, que lo europeo u occidental no constituye la única cosmovisión política posible. Otras obras igualmente recientes, a cargo de historiadores algunas de ellas, ponen igualmente de relieve cómo los modelos - políticos, económicos, religiosos- occidentales no pueden postularse como universales y generalizables a todo el orbe, por más que ese haya sido el intento $-\mathrm{y}$ en buena medida el logro- de Occidente. (Luque, 2011: 335)

Un último apunte. Aunque concentraré la mirada en las mentalidades, las rupturas que se produjeron dentro de esas mismas mentalidades, es decir, los metarrelatos políticos y económicos y más aún cómo las élites intelectuales construyeron esos metarrelatos hasta empapar el abanico del discurso social, quiero insistir en el carácter material, procesual, holístico, de las sociedades donde se incardinan dichas mentalidades. Sólo así podremos comprender, a mi juicio, de forma más cabal el impacto, alcance y significado de los movimientos de indignación (como el 15M) y hasta qué punto sus luchas están conectadas 
diacrónicamente con el devenir histórico mundial. En palabras del historiador británico E.P.Thompson:

El cambio en la vida material determina las condiciones de aquella lucha y algo de su carácter, pero el resultado concreto sólo está determinado por la misma lucha. Esto significa que el cambio histórico tiene lugar, no porque una «base» dada deba dar lugar a una «superestructura» correspondiente, sino porque los cambios en las relaciones productivas son experimentados en la vida social y cultural, refractados en las ideas de los hombres y en sus valores y razonados a través de sus acciones, sus elecciones y sus creencias. (Thompson, 2000: 43).

\section{La Gran Separación}

Cuando hablamos de separaciones y transformaciones, estamos refiriéndonos, antes de nada, a rupturas epistemológicas, cambios en los paradigmas (en sentido kuhniano) que pautan el modo de conceptualizar un fenómeno social. Al hilvanar las relaciones entre economía y política, considero pertinente rastrear, al menos, tres rupturas (siguiendo el modelo del antropólogo Enrique Luque). La primera tendría lugar durante la génesis de los Estados-Nación europeos (S. XVI-XVII) y supondría el desgajamiento (o separación) de la política frente a la religión, esto es, la independencia de la filosofía política respecto de la teología política cristiana. La segunda de las rupturas habitaría en los intersticios que alimentan la llustración y la Revolución Industrial (XVIIIXIX) y supondría la autonomización de la economía respecto de la política, el dibujo de un campo nuevo (lo económico) emancipado ya de su amarre estrictamente político (la acción de los gobiernos). La tercera (en la que aún nos encontramos) supondría el avance paulatino del dominio económico en un campo globalizado y la completa subordinación de la política a sus lógicas transnacionales. Recordemos, en este sentido, las imágenes con las que iniciábamos el texto. Al mismo tiempo (como ya he expresado al comienzo) estas tres rupturas constituyen tan sólo una forma ordenada de leer la historia, la hege-mónica, la que da cuenta de la retórica de la modernidad y génesis del capitalismo como si de un proceso evolutivo se tratara, cuando este modo de presentar los acontecimientos oculta, al menos, otros dos recorridos subalternos más amplios que modelan (y fundamentan) la propia estructura del capitalismo, a saber, "la matriz colonial del poder" en palabras de Walter Mignolo y la construcción de la división sexual del trabajo y la degradación de las mujeres a partir de la teoría feminista. Sin la concurrencia de estos recorridos-otros se hace muy difícil com-prender la envergadura del fenómeno y tampoco la significación de estos movimientos de indignación. Sin embargo, lo económico no es una categoría neutra, abstracta, monolítica, tiene apellidos, guarda una estrecha relación con las diferentes escuelas y especulaciones que han atendido sus contornos. Cuando hablamos de subordinación de lo político, esto es, de las formas de gobierno hacia lo económico, nos estamos refiriendo, sobre todo, a un modo de entender "lo económico" dominado por lecturas neoclásicas, liberales y/o neoliberales. Esta clase de miradas se han erigido en hegemónicas (en su sentido gramsciano) dentro de la academia occidental, configurando una "práctica y conciencia predominante" (Williams, 2003: 160). 
Es importante señalar esta diferenciación porque, en contraposición a esas mismas lecturas, cierta antropología ${ }^{4}$ y varios de los autores que repasaremos, vienen prestando una atención esencial a la economía política (el modo de interrelación entre ambos universos) no segmentándola, sino dando cuenta de la continuidad que existe entre sociedad-política-economía, aunque como nos señalara William Roseberry

Una parte del problema concierne al lugar que ocupa la «economía política» en la historia del pensamiento económico: su identificación con la economía política clásica desde Ferguson y los fisiócratas, pasando por Smith, Ricardo, Mill y - siguiendo una crítica que tras cuestionar las asunciones clásicas (por ejemplo, la teoría del valor trabajo), llevaría a conclusiones radicales- Marx. En este sentido, la economía política se distinguiría de la economía neoclásica en que esta última representó un cambio en la actitud intelectual que pasó de interesarse por «la riqueza de las naciones», a hacerlo por el precio de las judías; del valor cómo lo determina el tiempo de trabajo, al precio cómo lo determinan los mercados. (Moreno, 2004: 92)

Así que no nos extrañemos si, al intentar desbrozar esas relaciones, nosotros mismos caemos en las trampas propias de una dominación académica neoclásica.

Vayamos sintéticamente a la primera de las rupturas. Uno de los intelectuales que más ha reflexionado sobre este asunto es el norteamericano Mark Lilla. En su obra El Dios que no nació da cuenta de la separación entre política y religión en Occidente. Esta Gran Separación constituye el humus sobre el cual se ha levantado buena parte del edificio intelectual de nuestro mundo. Ahora bien, el itinerario que nos propone está plagado de recovecos. El punto de partida es una doble contradicción intrínseca que hereda el Cristianismo tras la definitiva disolución del Imperio Romano. Por un lado nos encontraríamos con una teología política (la cristiana), "un discurso sobre la autoridad política que se basa en un nexo divino" (Lilla, 2010: 30), instalada en la trascendencia y, por extensión, en las tensiones propias de una concepción orientada hacia el rechazo del mundo. Esta tendencia inscribirá en su perfil una difícil relación entre Dios-Hombre-Naturaleza, así como una gran ambigüedad relacional respecto de ese mismo mundo y sus dimensiones estrictamente políticas. Si lo comparamos, por ejemplo, con el Islam es fácil percibir algunas diferencias. La religión coránica germinó desde sus comienzos como teología y como filosofía política, vinculada coherentemente a una expansión territorial y a una necesidad pragmática de gobernar nuevos territorios, de ahí su eficacia y ductilidad. No así el Cristianismo que, en palabras del propio Lilla, se encuentra con un "Imperio accidental" (la caída de Roma) para el cual carece, en sus fundamentos doctrinales, de un proyecto unificado de organización. Ello

\footnotetext{
${ }^{4}$ Me estoy refiriendo, fundamentalmente, a la antropología económica vinculada a la corriente substantivista (Polanyi, Dalton, Bohannan). Para una definición sintética de esta corriente recogemos la siguiente descripción: "[...] los substantivistas rechazan el valor explicativo de la ley abstracta de la utilidad-escasez, así como el comparativismo continuista basado en tal presupuesto. Según ellos, los sistemas económicos están, por el contrario, en relación de discontinuidad radical. Esto obedece a su regulación mediante procedimientos principalmente no económicos." (Chauveau, 2005: 224).
} 
conduce a la segunda de las contradicciones, la constante inestabilidad de su arquitectura política y una historia plagada de disfunciones y enfrentamientos.

El número de oposiciones que encontramos en la vida y el pensamiento político medieval resulta extremadamente desconcertante. La Ciudad del Hombre se contraponía a la Ciudad de Dios, la ciudadanía política a la retirada monástica, el derecho divino de los reyes al derecho de resistencia, la autoridad de la Iglesia al antinomianismo, la ley canónica a la percepción mística, el príncipe al emperador, el emperador al Papa, el Papa a los concilios de la Iglesia. Toda política implica conflicto, pero lo que distinguía a la política cristiana era su inseguridad teológica y la intensidad de los conflictos que generaba: se trataba de unos conflictos que surgían de las ambigüedades más profundas de la revelación cristiana. (Lilla, 2010: 54).

La Baja Edad Media será un momento especialmente crítico donde contemplar todas esas tensiones. "Ciertamente, en los siglos XIV y XV se observan y se encuentran confirmadas formas de simbiosis entre religión y política, entre iglesias y estados. No obstante, se trata de formas nuevas, de relaciones diferentes, caracterizadas por divergencias e hiatos cada vez más explícitos y destinados a desembocar en divorcios y rupturas." (Tenenti, 2003: 10). Las hostilidades alcanzarán su cenit de manera dramática en los siglos XVI y XVII, en las llamadas "Guerras de Religión" y en la polarización europea entre Reforma y Contrarreforma. Un paisaje devastado y devastador que se erige en metáfora de una historia cultural dominada por esa concepción trascendente de lo religioso. Frente a tal estado de cosas reaccionarán los pensadores que protagonizarán la Gran Separación, y entre todos ellos aquel que primero profanará su sancta santorum: Thomas Hobbes. Su fin último será desmantelar "el complejo teológico-político de la cristiandad" (Lilla, 2010: 73), destruir su concepción teórica a partir de una tesis que, después, se alzará como basamento de los estados absolutistas en ciernes: "para entender la religión y la política, no necesitamos entender nada sobre Dios; solo necesitamos comprender al hombre tal y como lo encontramos, como un cuerpo solo en el mundo" (Lilla, 2010: 74) y para ello se hace imprescindible cambiar el miedo hacia Dios por la entrega de las voluntades a un soberano terrenal (el Leviatán) que, legitimado detrás de un contrato social y un uso coercitivo de la fuerza, asegurará la gobernabilidad y la estabilidad de la vida en comunidad, evitando que los seres humanos se maten los unos a los otros. Las puertas quedan así abiertas. Los asuntos políticos sólo conciernen a los hombres. Se acababa de levantar el primer andamiaje de un edificio teórico, la filosofía política, que será en adelante la piedra angular sobre la cual se irán superponiendo otras plataformas, otros armazones conceptuales. No obstante, debemos ser cautos: "La Gran Separación nunca fue un hecho consumado, ni siquiera en la Europa cristiana en la que se concibió por primera vez" (Lilla, 2010: 259). Muestra de ello lo encontramos en los trabajos que diferentes historiadores (George L. Mosse, entre otros ${ }^{5}$ ) han venido realizando sobre las formas rituales y religiosas de la política y su conexión con los discursos nacionalistas.

\footnotetext{
${ }^{5}$ Quisiera destacar, sobre todo, la siguiente obra: Mosse, G.L. (2005). La nacionalización de las masas, simbolismo político y movimiento de masas en Alemania desde las Guerras napoleónicas hasta el Tercer Reich. Madrid: Marcial Pons.
} 
Pero ya decíamos que el itinerario estaba plagado de recovecos. No es cuestión en este artículo de rastrear exhaustivamente todos ellos. Digamos tan sólo que a Hobbes le seguirán, primero, algunos críticos comprensivos vinculados con la democracia liberal como Spinoza, Locke, Montesquieu, Hume, Tocqueville. Luego, en plena Ilustración, surgirá el renacer religioso de un "Dios ético" (el Deísmo), cuyo tanteo pretenderá profundizar en las raíces antropológicas del pensamiento creyente tratando de volver a hermanar razón e impulso metafísico (religión sin revelación) por medio de las obras de Rousseau y Kant (destaquemos, en esta línea, el famoso pasaje roussoniano del Emilio, o De la educación correspondiente a la "Profesión de fe del vicario saboyano"); para concluir con la crítica de Hegel que supondrá un (re)posicionamiento de las relaciones entre religión y filosofía entendidas ambas como intentos por entender la totalidad de la experiencia: el conocimiento absoluto. Este decurso nos lleva a una última etapa (siglo XIX y principios del $\mathrm{XX}$ ) dominada por una teología liberal en la cual el objetivo era reconciliar las "verdades morales" con las "realidades de la vida política moderna" (Lilla, 2010: 261) en un marco de empuje del primer capitalismo. Una reconci-liación que, como ya ocurriera con las viejas guerras de religión, será enterrada dramáticamente de nuevo bajo las bombas y los muertos de la primera y la segunda guerra mundial.

La Gran Separación supone el desligamiento en Occidente (o, de forma más precisa, la problematización de la relación) entre filosofía política y teología política, convirtiéndose este maridaje en el sustrato sobre el cual tendrá lugar la siguiente de las rupturas: la autonomización de la economía respecto de la política. No obstante, para no perder de vista la herencia recibida que, de un modo u otro, todavía se introyecta en nuestras tensiones y contradicciones contemporáneas, me gustaría recordar una cita del propio Lilla bastante esclarecedora al respecto:

Aquellos de nosotros que hemos aceptado la herencia de la Gran Separación debemos hacerlo con sobriedad. Una y otra vez debemos recordar que vivimos un experimento, que nosotros somos la excepción. Tenemos pocas razones para esperar que otras civilizaciones sigan nuestro insólito camino, que comenzó por una crisis única de la teología política de la cristiandad. Esto no significa que otras civilizaciones carezcan necesariamente de los recursos para crear un orden político factible, sino que tendrán que encontrar los recursos teológicos de sus tradiciones para que eso ocurra. Nuestro reto es distinto. Hemos hecho una elección que es al mismo tiempo más sencilla y difícil: hemos decidido que nuestra política se limite a proteger a los individuos del mayor daño que puedan inflingirse unos a otros, a garantizar las libertades fundamentales y proporcionar un bienestar básico, y a dejar su destino espiritual en sus propias manos. Hemos apostado que es más prudente recelar de las fuerzas desatadas por la promesa mesiánica de la Biblia que intentar explotarlas para el bien público. Hemos elegido que la luz de la revelación no ilumine nuestra política. Si queremos que nuestro experimento funcione, tenemos que contar con nuestra propia lucidez. (Lilla, 2010: 267).

Esta lucidez cohabita, sin embargo, en un mundo poblado de saberes, de visiones-otras que no tienen por qué reconocer este linaje, asaeteado por 
distintas dinámicas que influyen sobre ella y que deben ser tenidas en cuenta a la hora de reflexionar en torno a la categoría de lo económico. Si atendemos, por poner sólo varios ejemplos, a algunas de las más significativas ocurridas tras los años sesenta y setenta, nos encontraríamos con el propio devenir del capitalismo y sus crisis cíclicas (las "ondas largas de la economía" que anunciara ya Nikolai D. Kontradieff en 1926) ${ }^{6}$; los procesos de colonización y descolonización; el impacto de la teoría de género y su (re)lectura de la historia político-cultural en clave no androcéntrica; el (re)posicionamiento del relativismo cultural en un intento por ofrecer visiones alternativas sobre "amplios patrones transhistóricos de la vida humana" (Brown, 2010: 28); las interdependencias centro-periferia todavía vigentes; el influjo del giro decolonial, su desobediencia epistémica y la propuesta de un pensamiento heterárquico dirigido a realizar otro análisis de los procesos del sistema-mundo a partir de una "corpo-política del conocimiento sin pretensión de neutralidad y objetividad" (Castro-Gómez y Grosfoguel, 2007: 21); la deconstrucción de las categorías de "Occidente" y "Tercer Mundo" realizadas por el feminismo postcolonial (Chandra Talpade, por ejemplo); las contradicciones tanto de los "estados-nación postcoloniales" (Comaroff, 2002: 89) como de los estados del bienestar adscritos tradicionalmente al mundo desarrollado; el resurgir de opciones políticas con un fuerte aroma religioso (como el Tea Party norteamericano); la revolución econó-mica neoconservadora amanecida a finales de la década de los setenta, sustentada académicamente por el paradigma de Milton Friedman y su Escuela de Chicago, así como por el impulso institucional ofrecido por las administraciones de Ronald Reagan y Margaret Thatcher; la revitalización hasta nuestros días de esa misma revolución neoconservadora en forma de ambiciosos programas de ajuste propug-nados por diferentes organismos multilaterales (Fondo Monetario Internacional, Banco Mundial, Unión Europea); la lucha intestina en el seno de la iglesia entre las posiciones doctrinales teocráticas robustecidas con el papado de Juan Pablo II y aquellas otras defendidas por los movimientos seglares, cristianos de base y la teología de la liberación latinoamericana; la creciente desigualdad social arraigada en sus dimensiones nacionales e internacionales (aumento de la brecha Norte-Sur); y así hasta un largo etcétera de interacciones psicológicas, sociales, políticas, económicas y culturales que interaccionan y siguen interaccionando en el seno de la ecología de esa Gran Separación.

\section{El ascenso de la ideología económica}

Pasemos a la segunda de las rupturas. Para ello tendré que volver al enfoque de Enrique Luque que aboceta con claridad los contornos de la misma:

El desgajamiento de la esfera política respecto a la religiosa ha servido como precedente y modelo de otro no menos importante. Me refiero al que se produjo

\footnotetext{
${ }^{6}$ Recordemos su famoso pasaje: "Puede considerarse hoy día como universalmente admitida la idea de que la dinámica de la vida económica en el orden social capitalista no es de carácter simple y lineal, sino complejo y cíclico. Sin embargo, la ciencia todavía está lejos de haber aclarado la naturaleza y tipos de estos movimientos cíclicos, ondulatorios." (Kontradieff, 1946: 2)
} 
bastante después entre política y economía. Hasta muy avanzando el siglo XVIII, incluida la época de Adam Smith, economía mantuvo su significado originario $\mathrm{y}$, por tanto, relativo al ámbito privado o doméstico. La misma economía política fue concebida como mera extensión al ámbito estatal de contextos y significados domésticos. La neta separación entre ambos dominios, político y económico, llegaría más tardíamente, con clara influencia de Smith, pero de la mano de Bentham y Ricardo. La ausencia deliberada de filosofía social en Ricardo y el más bien alicorto pragmatismo y utilitarismo de Bentham hacen muy diferente en magnitud la ruptura, si la comparamos con las dimensiones de la Gran Separación hobbesiana (Sabine, 1965). Pero las consecuencias, en cambio, han sido tal vez de mucho mayor calado. Como resaltó Carl Schmitt (1963) en su demoledora crítica de las consecuencias liberales de la revolución de Hobbes, lo que hoy supone la economía y sus ciclos es análogo a lo que hasta hace poco más de doscientos años significaba el mundo natural y sus catástrofes. (Luque, 2011: 339).

Tomando en consideración este aserto podemos observar cómo el proceso de autonomía de la economía respecto de la política se articula a partir del influjo del liberalismo y su concepción en torno al ser humano. Es ahí que aflora, en primer término, el que se postula por muchos teóricos como padre fundacional del alegato liberal, a saber, Adam Smith. Desde esta perspectiva, rastrear las bases de emancipación de la economía implicaría al mismo tiempo indagar en los funda-mentos socioculturales de construcción de ese discurso liberal, y esos fundamentos, a su vez, habría que escudriñarlos (por seguir con el viaje en forma de matrioska rusa) en la modelización del individualismo como asidero ontológico del pensa-miento occidental. Me ayudaré para ello de la obra del antropólogo francés Louis Dumont. "Para Dumont, la modernidad es eminentemente un plexo de instituciones regidas por un código central: el individualismo. El individualismo es una forma particular de producción cultural que consistiría en practicar la regla inversa del holismo: no es la relación lo que prima, como objeto de interés, sino el individuo sustancializado como entidad autónoma." (Díaz de Rada, 2003: 247-248). Quiero insistir en este concepto de "producción cultural", pues precisamente aquí radica la tesis central de este artículo, comprender que la autonomización de la economía frente a la política y, más aún, la subordinación de la segunda a la primera (tal y como estamos descubriendo, en toda su crudeza, durante la presente crisis) es, antes que nada, el resultado de un proceso histórico-cultural "provincial" (por utilizar el término de Chakrabarty), no universal, adscrito al modo específico en que Occidente racionaliza el mundo. Otras culturas, otras sociedades, mantienen formas bien distintas de vincular economía y política. Luego insistiremos en esta idea por medio del historiador italiano Giovanni Arrighi, para quién el cambio de hegemonía mundial (de EEUU a China) guarda relación, entre otros factores, con dos modos distintos de concebir el crecimiento económico y su relación respecto del poder político. Pero volvamos a Dumont. Veamos cuáles serían los elementos esenciales de su análisis en torno a la gestación y consolidación del individualismo, así como lo que denominó "ideología económica".

[...] Dumont dedicó su vida al estudio comparativo de las grandes civilizaciones. En vez de centrar su atención en los hechos sociales, las 
morfologías o la acción social de la modernidad, despliega su análisis al nivel de las ideologías, de los sistemas de ideas-valores que dotan a distintos modos de convivencia humana de significados contrastantes. Como antropólogo estaba convencido que "el respeto por el otro pasa por el respeto de los valores que subyacen a la vida de toda sociedad humana. La sociedad no es solamente una sección particular de la naturaleza ni una suerte de residuo despojado de significado propio, de pretensiones individuales. La sociedad es significado, dominio, y condición de significado (Dumont, 1987, énfais mío). Diferentes civilizaciones se distinguirían por su modo particular de concebir el lugar del individuo en relación con la sociedad. (Stolcke, 2011: 8)

En su libro clásico Homo aequalis: Génesis y apogeo de la ideología económica, el francés establece las coordenadas que marcarán el objeto de su recorrido analítico: "El «liberalismo» que ha dominado el siglo XIX y las primeras décadas del $\mathrm{XX}$, es decir esencialmente la doctrina del papel sacrosanto del mercado y sus concomitantes, reposa sobre una innovación sin precedentes: la separación radical de los aspectos económicos del tejido social y su construcción en un dominio autónomo." (Dumont, 1999: 17) Es por ello que su esfuerzo se centrará en transitar por los momentos y las obras que consolidaron esta "innovación sin precedentes". Hallaríamos un primer estadio de génesis de la separación, en cuyo seno se darían las condiciones de emergencia de la categoría económica y se irían trenzado los distintos eslabonamientos internos que van desde los fisiócratas (Quesnay a la cabeza) hasta la emancipación de lo político (Locke), alcanzando su propia moralidad (Mandeville) y consolidando su mirada autonomista de la mano de Adam Smith. Este primer estadio daría como resultado la eclosión del análisis marxista que, a juicio de Dumont y de forma claramente provocadora, constituye el auténtico apogeo de la separación entre las categorías de economía y política. Me detendré sólo un instante en la mirada que sobre Smith y Marx nos ofrece el antropólogo francés, para buscar después contrastes más contemporáneos de la mano de Arrighi.

Podríamos resumir la tesis principal de Dumont diciendo que para él 10 económico sólo consigue escapar a las limitaciones de la moralidad impuestas por la política asumiendo un carácter normativo propio, es decir, construyendo su propia moralidad. Pero este proceso constructivo vendría dado por, al menos, tres desplazamientos conceptuales: un primer "movimiento de emergencia de lo económico, designando con esta expresión la tendencia a acentuar un agente o un elemento único como una entidad autosuficiente - excluyendo o subordinando implícitamente otros agentes o elementos- que suministra la razón o el núcleo vital del dominio como un todo." (Dumont, 1999: 132); un segundo movimiento donde se da "una estricta congruencia entre las constricciones ideológicas generales que pesaban sobre la naciente economía y la orientación y el contenido mayores de la doctrina económica", en otras palabras, coherencia entre una moralidad propia, distinta, y un programa de acción sustentado en la "armonía natural de intereses, el laissez-faire, el libre comercio y finalmente el liberalismo económico como doctrina universalista" (Dumont, 1999: 133); para acabar con un tercer "deslizamiento de primacía" desde "las relaciones entre hombres hasta las relaciones entre los hombres y la naturaleza o más bien entre el hombre (en singular) y las cosas" (Dumont, 
1999: 134) cuyo corolario desnudaría la emergencia de la categoría de riqueza. ¿En qué autores cifra el francés la esencial madurez de estos tres desplazamientos? Pues, a su juicio, en la obra de Adam Smith y su teoría del valor-trabajo, y en el análisis marxista que termina por santificar una concepción del hombre entendido como individuo autosuficiente. Respecto de Smith lo escenifica del siguiente modo:

El creador de riqueza, de valor, es el hombre. El hombre y no ya la naturaleza como en Quesnay. Este hombre creador de valor es el hombre individual, en su relación viva, activa, con la naturaleza o la materia. Esta relación natural del hombre individual con las cosas se refleja en cierta medida en el intercambio egoísta entre hombres que, al ser un sucedáneo del trabajo, le impone su ley y permite su progreso. Como en la propiedad de Locke, es el sujeto individual el que es exaltado, el hombre egoísta tanto cambiando como trabajando, que con su esfuerzo, su interés y su ganancia, trabaja... por el bien común, para la riqueza de las naciones. (Dumont, 1999: 125).

Respecto del autor de El Capital nos propone la siguiente (re)visión:

Nos hallamos ante un joven intelectual romántico [el joven Marx], publicista y rebelde que quiere reconciliar y unir indisolublemente el pensamiento y la acción, y que con este fin se compromete a emancipar al hombre con la consigna: «El hombre es la esencia suprema para el hombre». Señalémoslo bien: no se trata esencialmente de un asunto de reforma de la sociedad o de liberación de una clase oprimida. La clase con «cadenas radicales» es sólo la condición necesaria de la emancipación absoluta de todos los hombres, o más bien de la emancipación del Hombre en abstracto, del Hombre por consiguiente como un ser autosuficiente y que encarna el valor supremo, del Hombre como un Individuo en el sentido perfecto, moderno del término. Además, la persona que pronuncia este voto lo hace evidentemente en tanto que Individuo, como un ser independiente liberado de sus cadenas, purgado de toda dependencia. (Dumont, 1999: 152).

Por debajo de estas dos lecturas dumontnianas pareciera colegirse (en beneficio de los postulados neoliberales y sin voluntad alguna por parte de su autor) una perspectiva del individualismo y los valores económicos (emancipados ya de lo político) presentados como la única posibilidad viable. Algo así como un paradigma bajo el cual todo lo que escapa a esta dimensión se presentaría como patológico, autoritario, irracional o salvaje. Los estados no individualistas, es decir, aquellos donde no opera esta separación radical entre economía y política (siguiendo esa lógica discursiva), tenderían a cercenar el libre intercambio y vulnerarían los derechos individuales. Si volvemos a las imágenes con que arrancábamos este texto y/o recorremos muchas de las noticias que los medios de comunicación nos ofrecen estos meses sobre la crisis financiera global, nos topamos con una fuerte coincidencia destacando el carácter inevitable, técnico, racional, del recetario neoliberal, en contraposición a aquellos estados/grupos sociales que, equivo-cadamente, "patológicamente" (siguiendo con la metáfora), insisten en apostar por un modelo de desarrollado 
orientado bien a la inversión pública y el crecimiento productivo, bien al decrecimiento ${ }^{7}$ y la impugnación del propio modelo.

Antes de abordar las críticas que el historiador Giovanni Arrighi formula a estas (re)lecturas dumontnianas, querría detenerme un instante en otro autor fundamental que, a mi juicio, constituye una pieza clave en el entramado de comprensión sobre el carácter (constructivo) cultural de la ideología económica individualista. Me estoy refiriendo a Karl Polanyi. Para este intelectual durante el siglo XIX se produce en Europa lo que denominó la Gran Transformación, el proceso de separación de la economía respecto de la sociedad y la política, conformando el auténtico origen de nuestro tiempo histórico. La Gran Transformación supone el proceso de ascenso y dominio de la economía de mercado. "La sociedad moderna, que nace en el siglo XIX, es una "sociedad de mercado", ya que el hombre, la tierra y la moneda son tratados en ella como mercancías. El proyecto de tal sociedad es el de "subordinar a las leyes del mercado la sustancia de la sociedad"" (Maucourant, 2006: 92). Por un lado tendríamos lo que denominó "El Molino Satánico", que implica la imposición del mercado autorregulado y el credo liberal como cosmovisiones dominantes dentro de la racionalidad occidental, algo que todavía pervive como argamasa de nuestras sociedades y gobiernos (tanto nacionales como transnacionales), mientras que por otro lado se produciría un proceso de resistencia civil ante tales fuerzas hegemónicas encarnado en la idea de autoprotección de la sociedad (el hilo rojo de la historia, cuya plasmación más inmediata la tenemos en el 15-M, el Movimiento de los Indignados). Digamos, antes de avanzar, que para Polanyi cualquier examen de lo económico debe integrar una visión substantivista, esto es, concebir el sistema económico como un proceso institucionalizado. La economía humana estaría incrustada siempre en instituciones económicas y no económicas, siendo esencial para su estudio el análisis pormenorizado de las formas históricas de integración economíacultura-sociedad. Dentro de estas formas históricas destacan tres: la "reciprocidad", la "redistribución", el “intercambio". (Polanyi, 2004: 233-260) Pues bien, a partir de esa concepción se adentra en la piedra filosofal del liberalismo, el mercado autorregulado, entendido como sistema económico controlado, regulado y dirigido sólo por los precios del mercado, de tal suerte que la producción y distribución de bienes y mercancías se encomiendan también a ese mismo mecanismo autorregulador. Luego, intenta desvestir y denunciar sus falseamientos. Recorde-mos, en esta dirección, dos fragmentos ya clásicos del propio Polanyi que, aún siendo extensos, creemos importante traer a colación:

Un mercado autorregulado requiere nada menos que la separación institucional de la sociedad en una esfera económica y una esfera política. En efecto, tal dicotomía es sólo la presentación, desde el punto de vista de la sociedad en su conjunto, de la existencia de un mercado autorregulado. Podría argüirse que la separación de las dos esferas se da en todo tipo de sociedad en todo momento. Pero tal inferencia se basaría en una falacia. Es cierto que no puede existir ninguna sociedad sin algún sistema de cierta clase que asegure el orden en la producción y distribución de los bienes. Pero ello no implica la existencia

\footnotetext{
${ }^{7}$ En línea con pensadores críticos como Serge Latouche, Richard Heinberg o James Howard Kunstler.
} 
de instituciones económicas separadas; normalmente, el orden económico es sólo una función del orden social en el que se contiene. Como hemos visto, ni bajo las condiciones tribales, ni feudales, ni mercantilistas, había un sistema económico separado en la sociedad. La sociedad del siglo XIX, en el que la actividad económica estaba aislada y se imputaba a una motivación claramente económica, constituyó en efecto una excepción singular. (Dumont: 2007: 121)

El punto crucial es éste: la mano de obra, la tierra y el dinero son elementos esenciales de la industria; también deben organizarse en mercados; en efecto, estos mercados forman una parte absolutamente vital del sistema económico. Pero es obvio que la mano de obra, la tierra y el dinero no son mercancías; en el caso de estos elementos, es enfáticamente falso que todo lo que se compra y se vende debe de haber sido producido para su venta. En otras palabras, estos elementos no son mercancías, de acuerdo con la definición empírica de una mercancía. El trabajo es sólo otro nombre para una actividad humana que va unida a la vida misma, la que a su vez no se produce para la venta sino por razones enteramente diferentes; ni puede separarse esa actividad del resto de la vida, almacenarse o movilizarse. La tierra es otro nombre de la naturaleza, que no ha sido producida por el hombre; por último, el dinero es sólo un símbolo del poder de compra que por regla general no se produce sino que surge a través del mecanismo de la banca o de las finanzas estatales. Ninguno de estos elementos se produce para la venta. La descripción de la mano de obra, la tierra y el dinero como mercancías es enteramente ficticia. (Polanyi: 2004: 123).

Mercancías ficticias y excepcionalidad cultural de la separación ${ }^{8}$. Dos cargas de profundidad contra los basamentos ideológicos de la gran tesis liberal. Así, en el proceso de autonomización de la economía se podrían observar varios fenómenos recursivos (en sentido moriniano ${ }^{9}$ ) que alcanzan nuestra modernidad y posmo-dernidad, una suerte de parteaguas donde, por un lado, se produce el afianzamiento de una sociedad de mercado organizada a partir de una lógica económica determinada (el mercado autorregulado); mientras que por otro lado secciones importantes de esa misma sociedad (amenazadas o, simplemente, dam-nificadas por esa realidad) tendrían que defenderse y autoorganizarse para resistir los envites de esa misma lógica de mercado. Nos hallaríamos ante una paradoja que, en nuestros días, alcanza unas dimensiones dramáticas, encarnadas en fenómenos bifrontes como los Planes de Ajuste en las economías mediterráneas europeas y la reacción ciudadana protagonizada por el movimiento del $15 \mathrm{M}$ en España y las luchas sociales en Grecia, Portugal e Italia.

\footnotetext{
${ }^{8}$ Carecemos de espacio para abordar otra de las proposiciones centrales de la teoría económica neoclásica en relación al mercado autorregulado, esto es, la elusión del concepto coste social y/o externalidad. Para algunos teóricos este concepto constituye uno más de los productos intelectuales emanados al final del siglo XVIII y principios del XIX, donde opera una separación radical entre Hombre y Naturaleza. A este respecto recomendamos el trabajo de Karl William Kapp y su análisis del coste social de la empresa privada.

9 "Un proceso recursivo es aquél en el cual los productos y los efectos son, al mismo tiempo, causas y productores de aquello que los produce." (Morin, 1997: 106)
} 
La historia social del siglo XIX fue así el resultado de un movimiento doble: la extensión de la organización del mercado en lo referente a las mercancías genuinas se vio acompañada por su restricción en lo referente a las mercancías ficticias. Mientras que los mercados se difundieron por toda la faz del globo y la cantidad de los bienes involucrados creció hasta alcanzar proporciones increíbles, una red de medidas y políticas se integraba en instituciones poderosas, destinadas a frenar la acción del mercado en relación con la mano de obra, la tierra y el dinero. Mientras que la organización de los mercados mundiales de mercancías, los mercados mundiales de capital y los mercados mundiales de dinero daba un impulso nunca antes visto al mecanismo de los mercados bajo la égida del patrón oro, surgía al mismo tiempo un movimiento profundamente arraigado para resistir los perniciosos efectos de una economía controlada por el mercado. La sociedad se protegía contra los peligros inherentes a un sistema de mercado autorregulado: éste fue el aspecto comprensivo en la historia de la época. (Polanyi, 2004: 127).

Después de este desvío conceptual necesario regresamos a Dumont y, especialmente, a las alternativas ofrecidas por Giovanni Arrighi respecto de algunas de sus tesis. Quiero detenerme, especialmente, en una de ellas. Me refiero a la (contra)lectura que el historiador italiano realiza de la obra de Adam Smith. Considero interesante consolidar este punto de vista por dos razones: primero, porque es en Smith donde Dumont sitúa el inicio de la madurez de la ideología económica individualista, y segundo porque para los teóricos neoliberales que hoy dominan buena parte del escenario académico intelectual, Smith vendría a ser el padre fundador que legitima sus posiciones doctrinales. Pues bien, la tesis heterodoxa y, hasta cierto punto, revolucionaria de Arrighi radica en el hecho de denunciar la tergiversación interesada que sobre su texto fundamental, La riqueza de las naciones, ha confeccionado la propia ideología neoliberal. Observemos en qué términos lo expresa:

Como ha argumentado muy fundadamente Donald Winch, la descripción smithiana de la economía política como «una rama de la ciencia del legislador o el estadista» y de su propia contribución como una «teoría», o conjunto de «principios generales» referida a la ley y el gobierno, es una caracterización muy precisa de sus intenciones y logros. Lejos de teorizar un mercado autorregulado que funcionaría mejor con un Estado minimalista o sin ningún Estado, La riqueza de las naciones, como La teoría de los sentimientos morales o las Lecciones de jurisprudencia (no publicada), presupone la existencia de un Estado fuerte capaz de crear y reproducir las condiciones para la existencia del mercado, que lo utilizara como instrumento eficaz de gobierno, que regulara el funcionamiento y que intervendría activamente para corregir o contrarrestar sus consecuencias social o políticamente indeseables. De hecho, el propósito de la economía política de Adam Smith era tanto «proporcionar al Estado [...] unos ingresos suficientes para mantener los servicios públicos», como «suministrar al pueblo una abundante renta o subsistencia, o hablando con más propiedad, habilitar a sus individuos y ponerlos en condiciones de lograrla por sí mismos». (Arrighi, 2007: 52).

La economía al servicio de la política. Un Estado fuerte capaz de corregir las insuficiencias del mercado. Justo la imagen opuesta que sobre este autor 
hemos recibido. No en vano (y volvemos otra vez a las estampas con las que iniciábamos este artículo) las medidas procíclicas de lucha contra el déficit público que avasallan hoy el discurso económico de los organismos multilaterales y los estados más poderosos, vendrían a orientarse en la dirección contraria de Adam Smith. Incluso se podría hablar (como el mismo Arrighi hace) de "marxismo neosmithiano", precursor, en cierta medida, tanto de posiciones socialdemócratas (redistribuidoras) como de la perspectiva económica keynesiana (uno de cuyos paradigmas fue el New Deal norteamericano de los años treinta).

En su magistral Adam Smith en Pekín, Giovanni Arrighi elabora un esfuerzo denodado por (re)situar los aportes del filósofo británico, y entre los muchos elementos que destaca querría rescatar, sobre todo, aquel que atesora una especial vinculación con el asunto que nos compromete. Si en un primer momento esbozábamos (vía Mark Lilla) la importancia de la Gran Separación con el objetivo de discernir la ruptura entre filosofía política y teología política cristiana, y luego ensayábamos los contornos de la Gran Transformación (vía Karl Polanyi y Louis Dumont) en un intento de dar cuenta del hiato entre economía y política mediante del fortalecimiento del discurso individualista; Arrighi compondrá un tercer concepto, la Gran Divergencia, mediante el cual esclarece las paradojas ocurridas a finales de los siglos XVIII y XIX en cuyo seno se articularon dos modos bien distintos de orientar el crecimiento económico: uno, el asiático, sustentado en la idea smithiana de "Revolución Industriosa" y de desarrollo no capitalista basado en el mercado, y otro, el occidental (de corte analítico schumpeteriano), encarnado en una "Revolución Industrial" y de desarrollo capitalista basado en el mercado. (Arrighi, 2007: 50). Sendas cosmovisiones han alimentado la deriva económica de los dos últimos siglos. Incluso se podría afirmar que, en línea con la tesis del propio Arrighi, el desplazamiento de la hegemonía mundial durante las últimas décadas desde el polo occidental (EEUU y Europa) hacia Asia (China, sobre todo), guarda relación con la continuidad de esa diferenciación de cosmovisiones. Occidente representaría la experiencia cultural ligada a la autonomización de la economía, mientras que Oriente (especialmente la China post Tian'anmen) personificaría la subordinación de la economía respecto del poder político. Busquemos dos nuevas postales que podrían ejemplificar este aserto. Por un lado el Banco Central Europeo con autonomía e independencia de decisión frente al Parlamento y la Comisión Europea (máximos órganos de decisión política), y por otro el sistema bancario chino, público, controlado estrictamente por el propio Partido Comunista, puesto al servicio de los intereses financieros de la industria y comercio nacionales.

No profundizaremos en las señas de identidad de cada una de estas dos cosmovisiones porque Giovanni Arrighi lo hace de manera mucho más fecunda. Tan sólo insistir en que fue Adam Smith el primero en identificar esa doble senda del desarrollo económico. A la Revolución Industriosa (que ya por entonces situaba en China) la denominó "progreso natural de la opulencia", mientras que a la Revolución Industrial (que nunca pudo contemplar en su desarrollada dimensión) la calificó como "retrógrada y contraria a la naturaleza" (Arrighi, 2007: 65). En conclusión, para Smith dos vías alternativas se abrían hacia la madurez económica: la europea (capitalista y de mercado) y la asiática 
(no capitalista y de mercado). Por eso su recomendación consistía en facilitar esa convergencia espontánea de la vía «antinatural» hacia la «natural», cuya plasmación en términos de política económica se traduciría del siguiente modo:

En esas circunstancias, el desarrollo «antinatural» excesivo del comercio exterior y de la industria se convierte en el principal obstáculo para que el gobierno central pueda promover el interés nacional. De ahí el consejo de Smith al legislador de contrarrestar el poder de los comerciantes y fabricantes haciéndoles competir entre sí y reducir los precios y los beneficios. En la primera situación la limitación principal del poder del gobierno central proviene del control de los terratenientes sobre los medios de violencia; en la segunda proviene del control de los comerciantes y fabricantes sobre la riqueza; pero en ambas situaciones la mayor preocupación de Smith es el establecimiento y preservación de la capacidad del gobierno central para promover el interés nacional. (Arrighi, 2007: 73).

Como podemos observar de nuevo, su traslación a la contemporaneidad más inmediata se desplegaría justo en dirección contraria al dogma neoliberal.

Acabo esta sección apuntando un último detalle de cierta relevancia que guarda una estrecha relación con todo lo adelantado hasta el momento. Esta separación de la economía y la política, todo el desarrollo ulterior de su andamiaje intelectual dentro de un entorno globalizado, ha producido numerosos efectos en la (re)configuración del propio hecho económico. Entre esos efectos contemporáneos quiero destacar uno que, a mi juicio, encierra y acumula dentro del orden hegemónico una fuerza discursiva enorme. Es lo que Nikolás Rose denomina "de-socialización del gobierno económico", es decir, el desanclaje territorial e institucional de la esfera económica, el traslado a la esfera puramente cognitivo-individual de la propia satisfacción de sus necesidades materiales. Este hecho lo podemos observar con bastante nitidez en el modo presente de capilarizarse el discurso sobre el papel económico de los Estados, de la ciudadanía (el mantra de los sacrificios a realizar por parte de todos) y, en definitiva, la apelación a extraer de nosotros mismos las mayores dosis de ingenio y creatividad ante una crisis sistémica irremediable y neutral.

[...] los problemas económicos del gobierno están siendo repensando en condiciones de una imagen revisada del espacio económico y de los medios, por los cuales se puede actuar sobre él. Parecería que, mientras los gobiernos nacionales aún deben administrar una población nacional, el bienestar económico de la nación y de su población ya no pueden ser simplemente superpuestos uno sobre otro y gobernados según el principio de maximización mutua. El gobierno de lo social, en nombre de la economía nacional, deja paso al gobierno de zonas particulares - las regiones, los pueblos, los sectores, las comunidades-, en vistas del interés de los circuitos económicos que fluyen entre regiones y a través de las fronteras nacionales. Los destinos económicos de los ciudadanos y gobiernos al interior de un territorio nacional se desacoplan, y pasan a ser entendidos y gobernados como una función de sus niveles particulares de emprendimiento, habilidad, inventiva y flexibilidad. (Rose, 2007: 127-128) 
En síntesis, uno podría sugerir que, dentro de esas estrategias de gobierno que he llamado "liberales avanzadas", se descubre la emergencia de un nuevo método de conceptualizar y actuar sobre las relaciones entre el gobierno de la vida económica y el auto-gobierno del individuo: la economía ya no ha de ser gobernada en nombre de lo social, ni ha de ser la economía la justificación del gobierno social en otra serie de sectores. Lo social y lo económico se ven ahora como antagónicos, y el esquema anterior debe ser fragmentado de modo de transformar las obligaciones morales y psicológicas de la ciudadanía económica en dirección a un auto-progreso activo. Simultáneamente, el gobierno de un rango de aparatos previamente sociales debe ser reestructurado de acuerdo con una imagen particular de lo económico: el mercado. El gobierno económico ha de ser de-socializado en nombre de la maximización del componente emprendedor de cada individuo. (Rose, 2007:129)

\section{Otros enraizamientos culturales de la autonomización económica}

Hasta aquí un recorrido en hilacha por algunos de los elementos que han macerado este modo concreto de ideología económica, el "credo liberal" (por seguir con la terminología de Polanyi). Dicha ideología ha señalado el camino en la autono-mización de la economía respecto de la política. Ahora bien, a lo largo del texto vengo insistiendo en el argumento de que este proceso constituye un producto sociocultural concreto, una seña distintiva de una cosmovisión específica, la occidental, en contraposición a otras. Pues bien, a mi parecer, para apuntalar esta tesis se hace necesario (re)tomar algunos aportes que amplían el escenario dibujado a lo largo de estas páginas. Para ello nos apoyaremos en las reflexiones en torno al concepto de "cultura" e "ideología" de Eric Wolf. Este autor cifró buena parte de su esfuerzo sistémico (en antropología política y económica) desde una intencionalidad clara por conectar las dimensiones tradicionalmente consideradas simbólico-culturales con las materiales (en línea con su filiación marxista). En su ya clásico Europa y la gente sin historia nos advierte:

Las "sociedades" afloran como alineamientos cambiantes de grupos, segmentos y clases sociales, sin contar ni con límites fijos ni con constituciones internas estables. Cada modo, en el ámbito de su influencia, genera conjunciones de grupos y clases que favorecen sus requerimientos bajo determinadas circunstancias históricas y geográficas. Estos requerimientos cambian, como también cambian los alineamientos resultantes. Cuando se cruzan modos de producción diferentes, las conjunciones de grupos llevarán la marca de las fuerzas de la acción recíproca. Por consiguiente, en vez de suponer que hay continuidad transgeneracional, estabilidad institucional y consenso normativo, debemos tratar a estos elementos como problemática. A estas características debemos entenderlas históricamente, observar las condiciones de su aflora-miento, mantenimiento y desaparición. En vez de pensar en alineamientos sociales como autodeterminantes, debemos, desde el inicio de nuestras indagaciones, visualizarlos en el seno de sus múltiples conexiones externas (Wolf, 2005: 467). 
Este modo de comprensión del hecho social obliga a (re)pensar el concepto de cultura y atender su carácter conectivo y problematizador. Sigue en ese sentido:

En cuanto ubicamos la realidad de la sociedad en alineamientos sociales históricamente cambiantes, imperfectamente unidos, múltiples y ramificados, nos hallamos con que el concepto de una cultura fija, unitaria y vinculada debe ceder el paso a un sentimiento de fluidez y permeabilidad de conjuntos culturales. Dentro de la rudeza de la interacción social, los grupos explotan las ambigüedades de las formas heredadas y les dan nuevas evaluaciones 0 valencias; toman prestadas formas que expresan mejor sus intereses, o bien, crean formas totalmente nuevas para responder a circunstancias nuevas. Además, si suponemos que esta interacción no es causativa en sus propios términos sino que responde a fuerzas económicas y políticas de más fuste, entonces, la explicación de formas culturales debe tomar en cuenta ese contexto más amplio, ese campo de fuerza más ancho. De este modo, "una cultura" se aprecia mejor como una serie de procesos que construyen, reconstruyen y desmantelan materiales culturales, en respuesta a determinantes bien identifi-cables. (Wolf, 2005: 468).

La construcción y reconstrucción de materiales culturales implicaría, por tanto, aceptar el uso instrumental de las formas culturales. Sin embargo, este uso tiene una incardinación tanto en la racionalización como en la comunicación y la praxis humana. Se trata de un proceso holístico que implica consecuencias lógicas pero también afectivas y estéticas. La capacidad de otorgar significados, de acercarse al mundo, como ilustra el propio Wolf, es en sí misma una fuente de poder. Ahí se gestan los principios de las ideologías, ahí germinan sus principales dimensiones, mas esta floración se produce dentro de un determinado tiempo histórico y bajo circunstancias concretas. Se hace inseparable el análisis de las ideologías de su nicho ecológico, histórico y productivo, por ello se trata de un producto cultural dentro de una marcada asignación contextual.

Esta capacidad de otorgar significados, de "nombrar" (dar nombre) a cosas, actos e ideas, es una fuente de poder. El control de la comunicación permite a los administradores de ideología establecer las categorías por medio de las cuales se va a percibir la realidad. Y a la inversa, esto lleva en sí la facultad de negar la existencia de categorías alternas, de asignarlas al reino del desorden y del caos, de volverlas social y simbólicamente invisibles. [...] Por consiguiente, la construcción y mantenimiento de un conjunto de comunicaciones ideológicas es un proceso social, que no puede ser explicado meramente como la actuación formal de una lógica cultural interna. El desarrollo de una pauta hegemónica general o "diseño para vivir" no es tanto la victoria de una lógica cognoscitiva colectiva 0 impulso estético cuanto el desarrollo de la redundancia, la repetición continua en diversos dominios instrumentales de las mismas proposiciones básicas sobre la naturaleza de la realidad inventada. (Wolf, 2005: 469). 
Si adoptamos esta concepción en el repaso de los asuntos que nos comprometen (vuelvo a recordar las estampas que inauguraban este texto), vemos cómo el recorrido diacrónico de autonomización de la economía, las recomendaciones actuales en relación a los Planes de Ajuste, la reducción del déficit, la disminución del Estado, políticas restrictivas todas ellas en materia de inversión pública, se erigen en "repeticiones" redundantes que tienen por misión asentar una serie de proposiciones hegemónicas sobre la realidad, generadas todas ellas en el corazón mismo de la ideología neoliberal. No se trataría, como se postula en ciertos discursos oficiales y medios de comunicación, de una estrategia estrictamente científica, técnica, neutral, sino una verdadera acción ideológico-capilar sustentada por unos paradigmas determinados (e interesados). Siguiendo esta argumentación creo esencial recuperar las tres funciones (fundamentos) que para Wolf tenía la ideología económica capitalista, a saber, y que todavía hoy (con más fuerza si cabe) mantienen una enorme vigencia:

Primero,

Las ideologías codifican estas distinciones no nada más como aspectos instrumentales de las relaciones sociales, sino como algo enraizado en la esencia misma del universo -en la naturaleza de la naturaleza, en la naturaleza de la naturaleza humana y en la naturaleza de la sociedad." (Wolf, 2005: 470).

Segundo,

En las sociedades dominadas por el modo capitalista, las distinciones de esencia aparecen en el concepto calvinista de que Dios premia la virtud y de que los que triunfan son virtuosos, o también en la idea de que la Naturaleza premia con las palmas del éxito a los triunfadores en la selección natural. Se piensa que la pobreza es muestra de falta de valor y de haber fracasado en la selección natural para merecer ocupar puestos de fuste. (Wolf, 2005: 470).

\section{Y tercero,}

En el modo capitalista la ideología reinante da por sentada la igualdad en el mercado de todos los participantes, aun frente a las distinciones básicas en cuanto a poderío económico y político entre capitalistas y trabajadores. Aunque en este modo se define a todos los actores sociales como participantes en el intercambio de mercancías, estructuralmente el modo depende del "desigual factor inicial" que se halla en propietarios de capital y vendedores de fuerza de trabajo. Así pues, la creación de ideología trasmuta la distinción entre clases en distinciones de virtud y mérito. (Wolf, 2005: 471).

En conclusión, el modo de producción de la ideología económica sustentada en el "credo liberal" y la autonomización de la economía conforma una "ecología de representaciones" (Wolf, 2005: 471) que ordena el mundo, selecciona opciones, incluye y excluye perspectivas, invisibiliza alternativas, combate ideacionalmente visiones divergentes, ejerce el poder material, solidifica instituciones, integra ciertos materiales culturales, desintegra otros, pone en 
valor estrategias capaces de fortalecer el sistema de organización social vigente, desprestigia aquellas que se desvían de su cosmovisión, revela como exógeno todo aquello que contraviene su propio dogma y, por resumirlo mediante una imagen utilizada estos días en los medios de comunicación, postula la no existencia de "Planes B" diferentes al suyo. Nos tendríamos que situar, por tanto, ante la cerrazón del monismo moral entendido como único edificio teórico posible.

La síntesis que querría dejar clara antes de abordar visiones alternativas al relato hilado hasta el momento, tal y como nos recuerda el propio Enrique Luque, es que atendiendo a la "polémica ubicuidad de la cultura" (Luque, 2005: 117-133) podemos postular que la supremacía de la economía sobre la política tal cual hoy la concebimos, y por extensión las reacciones "indignadas" ante tal supremacía (que están en la base de los movimientos críticos con la globalización y el $15 \mathrm{M}$ español), hunden sus raíces en un proceso cultural recursivo de autonomización de la economía (vuelvo al concepto moriniano) vinculado, a su vez, con la génesis, maduración y hegemonía de la ideología liberal, la cual ha recorrido la razón hegemónica occidental durante los últimos tres siglos. Este experimento cultural no es universal, no todas las sociedades conciben así la economía y la política aunque hayan sufrido sus efectos. Sin embargo, a partir de la forja de los estados-nación europeos durante los siglos XVI y XVII, de su expansión colonial, de la formación de sus imperios de ultramar basados en la explotación de recursos y personas, y posteriormente la articulación de un modelo capitalista global basado en el fundamentalismo del mercado autorregulado, se configura un "sistema-mundo" (Wallerstein, 2005) atravesado por esta ideología económica. Desatender esta herencia supone evitar los cimientos específicos de comprensión sobre los cuales levantar proyectos emancipadores críticos con ese estado de cosas.

\section{Impugnaciones al relato: dos heridas substantivas.}

Hasta aquí un modo de narrar las cosas. La autonomización de la economía vista desde estos miradores nos lleva a contemplar un paisaje determinado, coherente en su arquitectura, una suerte de mecánica de la historia atravesada por una cierta perspectiva teleológica. Quisiera volver a las imágenes con las que arrancábamos el relato, y proponer una más que introducirá nuevas metáforas analíticas y asaltará parte del argumentario hasta ahora expuesto. Regresemos a los días de génesis del movimiento $15 \mathrm{M}$ en España y, en concreto, a los instantes de la "Acampada Sol". Entre las muchas comisiones y grupos de trabajo generados se crea el espacio de "Feminismos Sol" cuyo objetivo era introducir las reivindicaciones feministas dentro del discurso del movimiento. Un gran cartel se suma a la miríada de nuevos ropajes que visten los edificios circundantes: "La revolución será feminista o no será." Aquí se resumía la idea fuerza. Sin embargo, desde el inicio este nuevo espacio topará con resistencias internas. Varias asambleas parecen no hacerse eco de las tesis defendidas por este grupo en comparación con otros aportes realizados en el resto de comisiones. Se empiezan, al mismo tiempo, a producir intimidaciones y agre-siones sexuales dentro de la propia acampada (en la mayoría de los casos no vinculadas a personas de la misma); incluso durante 
una de las numerosas manifestaciones celebradas esos días se produce un incidente aparentemente menor que, por el contrario, presenta una inquietante significación, se abuchea (por parte de una sección de los allí congregados) el despliegue de una pancarta feminista en uno de los edificios que rodean la plaza. Para algunos de los protago-nistas de este hecho la prioridad de la lucha social estaba en otro ámbito. El encadenamiento de estos sucesos cristaliza el 6 de junio de 2011 con la publicación en las redes sociales de un comunicado por parte de la comisión "Feminismos Sol" retirándose de la acampada", aunque no del movimiento ni de las acciones colectivas. Deseo detenerme en esta imagen porque enlaza simbólicamente con lo que a continuación quiero destacar. Del mismo modo que el relato hegemónico introduce en el proceso de autonomización de la economía en Occidente una serie de rupturas esenciales (la Gran Separación, la Gran Transformación, la Gran divergencia, etc.), se postergan, invisibilizan y olvidan otros elementos medulares que nos ayudan a comprender las razones de esta específica configuración sociocultural. Para ser más exactos, en línea con las tesis defendidas por la historiadora Silvia Federici, me sumo a la perspectiva por la cual no podemos comprender el alcance de esta construcción histórica sino la encastramos dentro del proceso más amplio de desarrollo capitalista (especialmente en las fases de acumulación primitiva de los siglos XV, XVI y XVII) sustentado en la privatización de la tierra en Europa, la generación de escasez, la separación de la producción respecto de la reproducción, el control del cuerpo femenino y, en resumen, la acumulación del trabajo y la degradación de las mujeres (por medio de la división sexual del mismo). En otras palabras, la "herida patriarcal" como uno de los vectores analíticos medulares en la construcción ideológica de la relación economía-política en Occidente, cuya plasmación se articula, entre otros, por medio de los si-guientes procesos (defendidos por la propia Federici):

1. La expropiación de los medios de subsistencia de los trabajadores europeos y la esclavización de los pueblos originarios de América y África en las minas y plantaciones del «Nuevo Mundo» no fueron los únicos medios para la formación y «acumulación» del proletariado mundial.

2. Este proceso requirió la transformación del cuerpo en una máquina de trabajo y el sometimiento de las mujeres para la reproducción de la fuerza de trabajo. Fundamentalmente, requirió la destrucción del poder de las mujeres que, tanto en Europa como en América, se logró por medio del exterminio de las «brujas».

3. La acumulación primitiva no fue, entonces, simplemente una acumu-lación y concentración de trabajadores explotables y capital. Fue también una acumulación de diferencias y divisiones dentro de la clase trabajadora, en la cual las jerarquías construidas a partir del género, así como las de «raza» y edad, se hicieron constitutivas de la dominación de clase y de la formación del proletariado moderno.

4. No podemos, entonces, identificar acumulación capitalista con liberación del trabajador, mujer u hombre, como muchos marxistas (entre otros) han hecho, o ver la llegada del capitalismo como un momento de progreso histórico. Por el contrario, el capitalismo ha creado las formas de esclavitud más brutales e insidiosas, en la medida en que inserta en el cuerpo del

10 Para leer el contenido del comunicado puede consultarse el enlace: http://www.emujeres.net/opinion/comunicado-comision-feminismos-sol 
proletariado divisiones profundas que sirven para intensificar y ocultar la explotación. Es en gran medida debido a estas divisiones impuestas -especialmente la división entre hombres y mujeres- que la acumulación capitalista continúa devastando la vida en cada rincón del planeta. (Federici, 2011: 190).

Estos itinerarios, sobre todo la primera tesis apuntada por Federici, ya nos alerta en torno a la siguiente de las heridas substantivas, a saber, "la herida colonial", otra posible senda de impugnación del relato tal cual lo hemos desbrozado hasta ahora. Sin entrar a desplegar los conjuntos analíticos que van de los enfoques post-coloniales (Gayatri Spivak, Edward Said, Hommi Bhaba, por ejemplo) a los estudios subalternos (Ranahit Guha, Dipesh Chakrabarty), pasando por la teoría decolonial (de fuerte raigambre latinoamericana y chicana, con figuras como Gloria Anzaldúa), me estoy refiriendo al peso que se debería otorgar precisamente al análisis de "lo colonial" a la hora de reconstruir el proceso de autonomización de la economía en Occidente. Más allá de una crítica sociohistórica hacia el modo de narrar y comprender el fenómeno de la modernidad, lo que subyace (para los intelectuales decoloniales) es la necesidad de "desprenderse" de ese modo de narrar, porque de no hacerlo se está condenado a repetir una y otra vez el mismo error, esto es, tomar la historia eurocéntrica como un universal, ocultar el imperialismo y la violencia colonial implícita en el ser mismo de la propia modernidad. Desde esta perspectiva la modernidad-racionalidad ha estado constituida por una colonialidad del poder ramificada (capilarmente, por utilizar la terminología foucoltiana) en diferentes órdenes y esferas: control de la economía, control de la autoridad y el poder, control de la naturaleza y de los recursos naturales, control del género y la sexualidad, control de la subjetividad y el conocimiento. A esta pléyade de niveles entrelazados la denomina "matriz colonial del poder" (Mignolo, 2010: 12) y constituyen el concepto difusor de buena parte de su perspectiva. Me gustaría destacar que esta matriz, a diferencia de las posiciones marxistas (recordemos la relación subordinada de infraestructura-superestructura) vincula el conocer (la epistemología) con el ser. "El control de la economía y de la autoridad (la teoría política y económica) dependen de las bases sobre las que se asiente el conocer, el comprender y el sentir." (Mignolo, 2010: 12). Para ello Mignolo toma los conceptos del sociólogo peruano Aníbal Quijano quién primero conectó (tras su paso por la teoría de la dependencia) el concepto de colonialidad con las estructuras de producción de conocimiento ("la parte invisible y constitutiva de la modernidad"), es decir, la vinculación entre ciencia y poder.

En un artículo publicado en 1989 (reimpreso en 1992) "Colonialidad y modernidad-racionalidad" Quijano explícitamente vincula colonialidad del poder en las esferas política y económica con la colonialidad del conocimiento y termina el argumento con la consecuencia natural: si el conocimiento es un instrumento imperial de la colonización, una de las tareas urgentes que tenemos por delante es descolonizar el conocimiento. (Mignolo, 2010: 10-11).

Ahora bien, ¿qué implica descolonizar el conocimiento? ¿en qué medida la modernidad-racionalidad es constitutiva del poder? Quijano nos lo dirá de un modo muy claro. La racionalidad occidental se caracteriza por su "ego-logia", 
por su carácter totalitario y excluyente de los otros modos de comprensión del mundo, su noción de totalidad expulsa a las márgenes de la historia los otros conocimientos y saberes "puesto que es una totalidad que niega, excluye, opaca la diferencia y las posibilidades de otras totalidades". (Mignolo, 2010: 13). Es por ello que si se quiere explicar el fenómeno de la modernidad (o cualquier otro derivado de su impacto) se hace necesario "desprenderse" de su matriz epistemológica. Implica abrirse a los otros mundos que también habitan este mundo.

El concepto de "colonialidad" tiene, a su vez, dos posibles usos. Uno de corte analítico y otro de coste programático. En el primer caso "la colonialidad ha abierto la reconstrucción y restitución de historias silenciadas, subjetividades reprimidas, lenguajes y conocimientos subalternizados por la idea de totalidad definida bajo el nombre de modernidad y racionalidad" (Mignolo, 2010: 14); en el segundo su orientación programática iría en la dirección de ese "desprendimiento" del que dábamos cuenta anteriormente. Pero volvamos a la pregunta que hacíamos antes. ¿Qué implica descolonizar el pensamiento? Pues, en opinión de Mignolo, escapar a una doble tentación: la que representa, por un lado, la crítica poscolonial (Said, Spivak y Bhabba), y la que encarna la teoría crítica (Horkheimer, Foucault, Lacan y Derrida). Ambas (aún siendo proyectos intelectuales críticos con la razón hegemó-nica de la modernidad) siguen inmersos en las operaciones propias de la academia europea y estadounidense, mientras que el "desprendimiento epistémico" tomaría como anclajes teóricos aquellas fuentes generadas en el vientre mismo de la comprensión/subjetivación del hecho colonial, esto es, Guamán Poma de Ayala, Ottobah Cugoano, Mhatma Ghandi, José Carlos Mariátegui, Amilcar Cabral, Aimé Césaire, Frantz Fanon, Gloria Anzaldúa, por poner algunos ejemplos.

La propuesta de Quijano debe ser leída en paralelo a su idea de un concepto no totalitario de totalidad; esto es, no una totalidad sin paréntesis (uni-versal) sino totalidades entre paréntesis, coexistiendo en la pluri-versalidad. La heterogeneidad histórico-estructural (regresaré más tarde a este concepto) desplaza la idea lineal de la historia imperial, eurocentrada, en la medida en que - por un lado- se concibe el acontecer histórico en su multiplicidad (nivel analítico) entrelazado por relaciones coloniales de poder que deberán ser descolonizadas en vista a la realización de la pluriversalidad como proyecto universal. (Mignolo, 2010: 16).

Desde esta posición, no habrá posibilidad de diálogo intercultural, de intercambio epistémico, si previamente no se produce ese "desprendimiento" radical conducente a una pluriversalidad efectiva. Además, tomando de Foucault el concepto de "corpopolítica", este desprendimiento implica deshacerse de la epistemología que subyace al "pienso, luego existo" de Descartes, para avanzar hacia el "se es donde uno piensa" que transformaría la "ego-logía" propia de la modernidad-racionalidad en una "geo-política" y "corpología" inscritas en la subjetivación del hecho colonial.

Uno de los proyectos intelectuales que se inscribirían (o, al menos, se inspirarían) dentro de este giro decolonial es el denominado "Antropologías del 
mundo". Sus impulsores, Gustavo Lins Ribeiro y Arturo Escobar, han promovido diversas publicaciones dirigidas a consolidar un verdadero diálogo de saberes, un auténtico intercambio epistemológico intercultural en el seno de la antropología y del conjunto de las ciencias sociales. Destaco este proyecto porque, a mi juicio, sus objetivos vienen a complementar de manera especialmente adecuada la comprensión cultural de la autonomización de la economía respecto de la política en Occidente y, en contraposición, los relatos impugnadores que estamos refiriendo en esta sección. Ahora bien, como señala la antropóloga Susana Narotzky, para que se pueda producir tal intercambio epistémico se hace necesario reconocer primero la co-presencia en el espacio y el tiempo de formas distintas de conocimiento con legitimidades propias y complementarias. Esta tesis es la que habita bajo el concepto de «coetanidad» defendido por Johannes Fabian de la Universidad de Ámsterdam.

[...] en su esfuerzo por historizar la práctica antropológica y encontrar una saluda a las formas dominantes de producción de conocimiento. Su aporte enfatiza la inevitable coetanidad de la comunicación no sólo en el encuentro de campo sino también en el encuentro con otras formas de conocimiento producidos a través de la confrontación polémica. Esta última implica el reconocimiento de la co-presencia conceptual, convocándonos a debatir con las formas de conocimiento en tanto son realidades actuales $-\mathrm{y}$ políticas - y no como si fueran algo cerrado en un pasado que no es más o que está en una esfera de la producción cultural distinta del conocimiento. (Narotzky: 2008, 175)

Como podemos observar, este concepto retroalimenta la perspectiva de Mignolo, asentado una base para el diálogo y la generación de pensamiento crítico subalterno impugnador del relato hegemónico.

Quisiera cerrar, por tanto, este texto ubicando algunas otras sinergias que amplían la propuesta decolonial esbozada hasta aquí y que ponen el acento en lo que podríamos considerar como una tercera herida substantiva, a saber, "la herida epistémica", aquello que incide especialmente en la "colonialidad del conocimiento". Empiezo por rescatar la "crítica de la razón teórica" de Pierre Bourdieu. El sociólogo francés arremete contra el objetivismo científico (uno de los sancta santorum de la modernidad-racionalidad dentro de la cual se fue gestando la autonomización de la economía) y su conexión con el estatuto de poder. En este sentido, a pesar de que posiblemente Walter Mignolo ubicaría a este autor dentro de los herederos de la teoría crítica (en contraposición a la opción liberadora propia del discurso decolonial), considero sus advertencias y reflexiones en torno a la razón teórica occidental muy próximas a la visión que Quijano nos presentaba sobre la colonialidad del conocimiento. Así, el francés, introduciéndose en la propia economía política del conocimiento en ciencias sociales nos indica lo siguiente:

La ciencia social no solamente debe, como lo pretende el objetivismo, romper con la experiencia indígena y la representación indígena de esa experiencia; mediante una segunda ruptura, necesita además poner en cuestión los presupuestos inherentes a la posición del observador "objetivo" que, además, de interpretar prácticas, tiende a importar en el objeto los principios de su relación con el objeto, como lo testimonia por ejemplo el privilegio que concede 
a las funciones de comunicación y de conocimiento y que lo inclina a reducir las interacciones a puros intercambios simbólicos. (Bourdieu, 2008: 46)

Y continúa, haciendo gala de un carácter autocrítico y reflexivo poco común:

Pero el más temible de los obstáculos para la construcción de una adecuada ciencia de la práctica reside sin duda en el hecho de que la solidaridad que liga a los doctos en su ciencia (y en el privilegio social que la hace posible y que ella justifica o procura) los predispone a profesar la superioridad de su saber, a menudo conquistado al precio de inmensos esfuerzos, contra el sentido común, incluso a encontrar en esa superioridad una justificación de su privilegio, en lugar de producir un conocimiento científico del modo de conocimiento práctico y de los límites que el conocimiento dicto debe al hecho de que reposa sobre el privilegio. (Bourdieu, 2008: 48)

Este carácter corporativo, de alineamiento y superioridad, se traduce en un distan-ciamiento "ego-lógico" (por seguir con la terminología de Mignolo) que reifica (desproblematizándola) la relación entre observador y observado. Leámoslo mejor en sus propias palabras:

El intelectualismo es, si se me permite la expresión, un intelectualismo que conduce a colocar en el principio de la práctica analizada, a través de las representaciones construidas para explicarla (reglas, modelos, etc.), la relación con el mundo social que es precisamente la del observador y, por ese medio, la relación social que hace posible la observación. (Bourdieu, 2008: 49).

Es precisamente este carácter autocrítico del pensamiento teórico racional el que, a mi juicio, emparenta a Bourdieu con las aproximaciones decoloniales de Mignolo y Quijano.

Otra aportación complementaria la encontramos en el concepto (ya referido anteriormente) de "pensamiento complejo" de Edgar Morin. Para este filósofo la "racionalización" occidental (que no racionalidad), es decir, el modo en que se organiza epistemológicamente el conocimiento, produce una "patología del saber" (la inteligencia ciega) que iría justo en dirección contraria del saber. O mejor dicho, esta patología lejos de comprender los hechos de manera compleja, interrelacionada, los simplifica y aísla. "Vivimos bajo un imperio de los principios de disyunción, reducción y abstracción, cuyo conjunto constituye lo que llamo el «paradigma de simplificación»." (Morin, 1997: 29). ¿Qué se obtiene como resultado de esta simplificación? Una imagen separada, un distanciamiento entre lo cognoscible y el sujeto cognoscente (en línea con la crítica formulada por Bourdieu), y justo en esa separación es donde se produce el ensoberbecimiento de ese mismo sujeto cognoscente convertido así en un pequeño dios, poderoso en su hacer, ensimismado en su método, insensible ante los otros modos de saber, pero alejado de la comprensión plural de lo real.

Y así toma forma el paradigma clave de Occidente: el objeto es lo cognoscible, lo determinable, lo aislable y, por lo tanto, lo manipulable. Contiene la verdad objetiva pero al ser manipulable por la técnica, es nada. El sujeto es lo desconocido, desconocido por indeterminado, por espejo, por extraño, por 
totalidad. Así es que en la ciencia de Occidente, el sujeto es el todo-nada; nada existe sin él, pero todo lo excluye; es como el soporte de toda verdad pero, al mismo tiempo, no es más que «ruido» y error frente al objeto. (Morin, 1997: 69).

Frente a este estado de cosas, Morin reacciona proponiendo un paradigmaotro, una "epistemología abierta", basada en la unidad de la ciencia, que sea capaz de integrar las realidades expulsadas por la ciencia clásica occidental, orientada a lo que denomina un "cambio paradigmático" y que trate de (re)nombrar los hechos mediante un territorio de unión entre procesos de simplificación (selección, jerarquización, separación y reducción) y "contraprocesos" que impliquen comuni-cación, articulación, recursividad, incertidumbre y globalidad. A esta propuesta la llama "pensamiento complejo." De ahí que su denuncia de la racionalización occidental sea radical:

Pero ese paradigma de Occidente, hijo de la herencia fecunda de la esquizofrénica dicotomía cartesiana y del puritanismo clerical, gobierna también al doble carácter de la praxis occidental, por una parte antropocéntrica, etnocéntrica, egocéntrica, cuando se trata del sujeto (porque está fundada sobre la auto-adoración del sujeto: hombre, nación o etnia, individuo); por otra parte y correlativamente manipuladora, congeladamente «objetiva», cuando se trata del objeto. Ese paradigma no existe si no es en relación con la identificación de la racionalización con la eficacia, de la eficacia con los resultados cuantificables; es inseparable de toda una tendencia clasificatoria, reificatoria, etc., tendencia corregida, a veces fuertemente, apenas otras veces, por contra-tendencias aparentemente «irracionales», «sentimentales», románticas, poéticas. (Morin, 1997: 83).

Desde mi perspectiva, el "paradigma de la complejidad" moriniano, también podría dialogar con el concepto de "desprendimiento epistémico" sostenido por Quijano y Mignolo. Aún siendo una apuesta emancipadora y no liberadora (en los términos expresados por el enfoque decolonial), creo que apuesta decididamente por levantar un pensamiento-otro sostenido sobre fundamentos inclusivos que visibilicen los demás saberes y den cuenta de los fenómenos socio-económicos desde una visión compleja, holística y, por qué no, también poscolonial.

Y cierro ya con la última de las aportaciones complementarias, la de Boaventura de Sousa Santos, especialmente su apuesta por "descolonizar Occidente" y transitar hacia una "ecología de saberes". "La ecología de saberes está basada en la idea pragmática de que es necesario revalorizar las intervenciones concretas en la sociedad y en la naturaleza que los diferentes conocimientos pueden ofrecer." (de Sousa Santos, 2010: 38). En aras de este objetivo, el sociólogo portugués comienza por denunciar lo que considera el rasgo esencial del pensamiento occidental moderno, a saber: el "pensamiento abismal".

Éste consiste en un sistema de distinciones visibles e invisibles, las invisibles constituyen el fundamento de las visibles. Las distinciones invisibles son establecidas a través de líneas radicales que dividen la realidad social en dos 
universos, el universo de "este lado de la línea" y el universo del "otro lado de la línea". La división es tal que "el otro lado de la línea" desaparece de la realidad, se convierte en no existente, y de hecho es producido como no existente. No existente significa no existir en ninguna forma relevante o comprensible de ser. Lo que es producido como no existente es radicalmente excluido porque se encuentra más allá del universo de lo que la concepción aceptada de inclusión considera es su otro. Fundamentalmente lo que más caracteriza al pensamiento abismal es pues la imposibilidad de la copresencia de los dos lados de la línea. Este lado de la línea prevalece en la medida en que angosta el campo de la realidad relevante. Más allá de esto, sólo está la no existencia, la invisibilidad, la ausencia de dialéctica. (de Sousa Santos, 2010: 11-12)

Sobre esta tesis se levanta una arquitectura epistémica segregadora, imperial, basada en las divisiones entre regulación/emancipación y apropiación/violencia, que expulsa a los márgenes de la historia del conocimiento no sólo saberes ajenos a su propia tradición ("el otro lado de la línea"), sino también aquellos que, aún inscribiéndose dentro de la misma, cuestionan o ponen el acento en la necesidad de co-existir con otros mundos intelectuales y dudar de su propia jerarquía (apertura hacia un "Occidente no occidentalista"). Autores como Luciano de Samósata, Nicolás de Cusa o Blas Pascal (por citar los tres filósofos abordados por el portugués en varios de sus textos) vendrían a encarnar esa "expulsión interna" dentro del paradigma de la racionalidad/colonialidad de Mignolo.

La apuesta de Boaventura por la ecología de saberes, por la descolonización de Occidente, por la furiosa crítica al pensamiento abismal que lo cauteriza, por un pensamiento ecológico sustentado en la copresencia (en línea con el concepto de "coetanidad" de Fabian), por la ciencia moderna incrustada dentro de esa misma ecología de saberes sin rango de dominio ni privilegio de verdad, por la recuperación de aquellas obras y autorías dentro de la propia tradición europea que apostaron (y aún hoy apuestan) por la "docta ignorancia" y la convivencia intelectual, en definitiva, por un replanteo estructural de las bases de conocimiento generadas por la modernidad/colonialidad, hacen de su obra una referencia en diálogo con las tesis decoloniales.

En resumen, la reconstrucción cultural (aunque sea en hilachas) de la autonomización de la economía respecto de la política en Occidente amerita de una impugnación epistémica, urge desbordar el conjunto de materiales analíticos (re)introduciendo la perspectiva feminista y decolonial allí donde sea necesario, problematizando las bases fundacionales de su estatuto científico. No dar por completo y auténtico aquello que es una mera reconstrucción histórica parcial e interesada. 


\section{BIBLIOGRAFÍA}

(2007) ARRIGHI, G. Adam Smith en Pekín. Orígenes y fundamentos del siglo $X X I$, Akal, Madrid.

(2010) BROWN, Michael F. "Relativismo 2.0". En Cruces Villalobos y Pérez Galán (Comp.), Textos de la Antropología Contemporánea, UNED, Madrid.

(2008) BOURDIEU, Pierre. El sentido práctico, Madrid, Siglo XXI.

(2007) CASTRO-GÓMEZ, Santiago y Grosfoguel, Ramón. El giro decolonial: reflexiones para una diversidad epistémica más allá del capitalismo global. Siglo del Hombre Editores; Universidad Central, Instituto de Estudios Sociales Contemporáneos y Pontificia Universidad Javeriana, Instituto Pensar, Bogotá.

(2005) CHAUVEAU, J.P. "Económica (Antropología)". En Bonte, P. y Izard, M. (Eds.), Diccionario de Etnología y Antropología, (pp. 224-227), Akal, Madrid.

(2002) COMAROFF, Jean y John. "Naturalizando la nación: aliens, Apocalipsis y el estado postcolonial", Revista de Antropología Social, 11, ISSN 1131-558X, pp 89-133.

(2010) DE SOUSA SANTOS, Boaventura. Para descolonizar Occidente. Más allá del pensamiento abismal, Buenos Aires, CLACSO.

(2003) DÍAZ DE RADA, Ángel. "Las formas del holismo. La construcción teórica de la totalidad en etnografía", Revista de dialectología y tradiciones populares, Tomo 58, Cuaderno 1, ISSN 0034-7981, pp 237-262.

(1999) DUMONT, Louis. Homo aequalis. Génesis y apogeo de la ideología económica, Taurus, Madrid.

(2011) FEDERICI, Silvia. Calibán y la bruja. Mujeres, cuerpo y acumulación originaria, Traficantes de sueños, Madrid.

(1946) KONTRADIEFF, Nikolai y Garvy, G. Las ondas largas de la economía, Revista de Occidente, Biblioteca de la Ciencia Económica IV, Madrid.

(2001) KUHN, Thomas. La estructura de las revoluciones científicas, Fondo de Cultura Económica, México.

(2010) LILLA, Mark. El Dios que no nació. Religión, política, y el Occidente moderno, Debate, Barcelona.

(1990) LUQUE, Enrique. Del conocimiento antropológico, Siglo XXI, Madrid.

(2005) LUQUE, Enrique. "La polémica ubicuidad de la cultura", En Varios autores, Estructura y procesos sociales. Libro homenaje a José Cazorla, Centro de Investigaciones Sociológicas, Madrid, pp 117-133. 
(2011) LUQUE, Enrique. "De Leviatán al Toro de Wall Street", Revista de Antropología Social, 20, ISSN 1131-558, pp 333-346.

(2001) MARCUS, George. "Etnografía en/del sistema-mundo. El surgimiento de la etnografía multilocal", Alteridades, 11 (22), ISSN ISSN: 0188-7017, pp 111127.

(2006) MAUCOURANT, Jérôme. Descubrir a Polanyi, Edicions Bellaterra, Barcelona.

(2010) MIGNOLO, Walter. Desobediencia epistémica. Retórica de la modernidad, lógica de la colonialidad y gramática de la descolonialidad, Buenos Aires, Ediciones del Signo.

(2004) MORENO FELIU, Paz (comp.). Entre las Gracias y el Molino Satánico: Lecturas de antropología económica, UNED, Madrid.

(1997) MORIN, Edgar. Introducción al pensamiento complejo, Gedisa, Barcelona.

(2005) MOSSE, George L. La nacionalización de las masas, simbolismo político y movimiento de masas en Alemania desde las Guerras napoleónicas hasta el Tercer Reich, Marcial Pons, Madrid.

(2008) NAROTZKY, Susana. "La producción de conocimiento y de hegemonía. Teoría antropológica y luchas políticas en España", En Lins Ribeiro, Gustavo y Escobar, Arturo (eds.), Antropologías del mundo. Transformaciones disciplinarias dentro de sistemas de poder, (pp.165-189). Popayán (Colombia), Envión Editores.

(2004) POLANYI, Karl. "El sistema económico como proceso institucionalizado". En Moreno Feliu, P. (comp.). Entre las Gracias y el Molino Satánico: Lecturas de antropología económica, UNED, Madrid, pp 233-260.

(2004) POLANYI, Karl. La Gran Transformación. Los orígenes políticos y económicos de nuestro tiempo, Fondo de Cultura Económica, México.

(2001) STOLCKE, Verena. "Gloria o maldición del individualismo moderno según Louis Dumont", Revista de Antropología, São Paulo, ISSN 0034-7701, v. 44 , ำ2.

(2008) TALPADE, Chandra. "Bajo los Ojos de Occidente: Feminismo Académico y Discursos Coloniales". En Hernández Castillo, R. y Suárez Navaz, L. (coord.), Descolonizando el Feminismo: Teorías y Prácticas desde los Márgenes, Cátedra, Madrid, pp 112-161.

(2003) TENENTI, Alberto. La Edad Moderna. Siglos XVI-XVIII, Crítica, Barcelona. 
(2000) THOMPSON, Edward Palmer. Agenda para una historia radical, Crítica, Barcelona.

(2005) WALLERSTEIN, Immanuel. Análisis del sistema-mundo. Una introducción, Siglo XXI, México.

(2006) WILLIAM KAPP, Karl. Los costes sociales de la empresa privada (Antología), Los Libros de la Catarata, Madrid.

(2003) WILLIAMS, Raymond. Palabras clave. Un vocabulario de la cultura y la sociedad, Nueva Visión, Buenos Aires.

(2005) WOLF, Eric. Europa y la gente sin historia, Fondo de Cultura Económica, México. 